\title{
Celebration of a dead genius
}

The second centenary of Michael Faraday's birth is being celebrated in Britain with great style, but in a way that inevitably provokes regret as well as pride.

\begin{abstract}
"Now I know what's wrong with British science", said a sharp-tongued mid-Atlantic person at the end of last Friday evening's glittering occasion at the Royal Institution of London: "It's the cult of the amateur. People in dinner-jackets doing magic tricks for other people in dinner jackets." The complainant had forgotten that, until recently, the performers had been required to wear white ties and the tail-coats that go with them. (Then, as now, there were hardly ever women.) And, in any case, last Friday's show (for that it was) was a nostalgic evocation of times past by people now alarmed about the future.
\end{abstract}

The occasion was part of a veritable season of celebration of the second centenary of the birth of Michael Faraday, on 22 September 1791. (The celebrations will go on at least until Faraday's portrait is replaced on the verso of the $£ 20$ British banknote.) The men in black ties were the two immediate past directors of the Royal Institution - Lord Porter (president of the Royal Society until a year ago) and Sir John Meurig Thomas, who was succeeded in the summer by Dr Peter Day and who now divides his time between structural chemistry and running what many consider to be the unrunnable - Britain's University of Wales.

The setting is unique, indeed unbeatable, so to speak. In down-town London, two hundred yards across Piccadilly from the Ritz Hotel and almost immediately opposite Brown's Hotel, there is a colonnade of fake Grecian columns (put up in 1838) concealing the London-brick structure in which Count Rumford (otherwise Benjamin Thompson, who had fled the United States after being accused of spying) founded in 1799 a centre for the popularization of the "mechanical arts".

The fake colonnade is a perpetual headache for the managers of the place, who are often advised that, unless they spend sums of money they believe they cannot afford, it may come loose from the structure it adorns. That encloses a lectureroom of artless but unsurpassed design half a hemisphere, of radius is no more than six or seven metres, in which more than 400 people (when the uncomfortable balcony is full) can hear the man in the black tie at the centre even if he whispers. Humphry Davy (who succeeded Rumford) evidently had in mind an anatomy theatre in which the exhibits would not be living bodies or cadavers but demonstrations of the mechanical arts.

Showmanship is the essence of the Royal Institution, which is thereby true to Rumford and to Davy (who told a friend of his own "weak, glorious, pitiful, sublime conceited egotism"). Even now, the set-piece lectures, called discourses, are held on Friday evenings, are timed to begin exactly at 9 p.m. and to finish exactly 59 minutes and 50 seconds later. Demonstrations (and the applause they prompt, especially when they end in loud bangs) play a crucial part, but take literally incalculable seconds. If speakers cannot ad lib (or abbreviate in mid-peroration), the striking of the clock may be surreptitiously delayed.

Last Friday's practised performers required no such artifice. One (Porter) started bang on time and the other (Thomas) finished just on the witching hour. Between them, they managed more than one demonstration every three minutes.

Porter, acting as if relieved that the constraints of being president of the Royal Society have been sloughed off, delivered the more elegant half-discourse. His jokes were mostly half-sentences, not even oneliners. His barbs were distributed to politicians, administrators and researchers in equal measure. At one point, he sat inside an electrically conducting cage charged by an electrostatic machine to show, with the help of an electroscope and an insulated wand carrying coloured tufts of wool, that the electric charge of a conducting body lies on the surface - as Faraday had done at the same spot in 1836 .

Thomas, no less accomplished, has a different style. Controlled passion, called $h w y l$ by people of his Welsh cultural persuasion, restrains side-swipes at innocent bystanders and is best fitted to solemn occasions - funerals certainly, birthday celebrations (even 200 years on) perhaps. Yet this was the half-discourse that reminded the audience that Faraday was first a chemist and only afterwards the founder of electromagnetism.

Thomas's most evocative demonstration, tenuously linked with Faraday's celebrated lectures on "The Chemical History of the Candle", had an assistant (also in black tie) pouring a bucketful of carbon dioxide evaporated from dry ice into a container on one side of a crude balance arm to show that the density of carbon dioxide is greater than that of air. Two weeks earlier, as part of the same celebrations, Sir John Cadogan (research director of British Petroleum) had in the same spot used gas chromatography to show that the benzene isolated and chacterized by Faraday in 1825 was 99.7 per cent pure.

That Faraday was a genius, and an Englishman to boot, is not disputed. Welsh Thomas came close to English heresy last Friday in comparing him to Newton, but he will be forgiven. What the glittering occasion also showed is that, for the Royal Institution, Faraday is a domestic genius whose presence is still felt. For half a century after he was hired by Davy in 1812, he lived and worked at the Royal Institution, leaving his meticulous notebooks for the scholars who still pore over them. Last Friday, they were showing off these volumes as well as his notes taken at four of Davy's lectures, bound by Faraday himself, with which this untutored person had introduced himself to his employer.

It was, in short, a great and sentimental occasion, to which people had been invited jointly by the Royal Society and the Royal Institution. How could it have evoked even a scintilla of sourness?

The black-tie part is irrelevant. In Davy's mind, the Royal Institution was a means of making propaganda for the mechanical arts among the well-to-do of Mayfair and thus of raising money for research. Over the years, the Davy-Faraday laboratories occupying the less grand upper rooms have indeed sheltered people such as John Tyndall (one of the most prolific contributors to Nature after its foundation in 1869) as well as, more recently, J.D. Bernal, Kathleen Lonsdale and Max Perutz. Faraday himself said that the need to perfect experiments for the weekly discourses spurred his scientific work. As the French are now well aware, there is no harm, but a power of good and even public profit, in banging the drum for research among the rich and influential.

It matters more that Faraday's heroic tale is in danger of becoming hackneyed in the retelling. True, he was a blacksmith's son, but the modern middle classes had hardly been invented then. And there is a danger that dwelling on his undisputed innocence of mathematics may recreate the impression that the mechanical arts are, or should be, simple after all. Ministers in last Friday's audience may even have left with the impression reinforced that British science would not be complaining about its budget if its practitioners were half as smart as Faraday. 